\title{
T10 - Adaptación y rendimiento de plantas autóctonas de Guatemala en un sistema acuapónico
}

\author{
Carlos Valdez-Sandoval*, Dennis Guerra-Centeno, Edvin Aquino-Sagastume, \\ Mercedes Díaz, Ligia Ríos \\ Facultad de Medicina Veterinaria y Zootecnia, Universidad de San Carlos de Guatemala
}

*Autor al que se dirige la correspondencia: 200valdez@gmail.com

\section{Resumen}

Se determinó la adaptación y rendimiento de ocho variedades de plantas autóctonas de Guatemala en un sistema acuapónico. Se utilizaron siete módulos acuapónicos, con capacidad de 80 plantas y 25 organismos de tilapia nilótica (Oreochromis niloticus). Se incluyeron en el estudio, plantas de apazote (Dysphania ambrosioides), makuy (Solanum nigrescens), amarantos (Amaranthus sp.), bledo (A. cruentus), chipilín (Crotalaria longirostrata), chipilín montés $(C$. vitellina) ayote (Cucurbita argyrosperma) y güicoy (C. pepo). El periodo de evaluación fue de 60 días. Se registró la supervivencia (S), tamaño (T), peso (P) y biomasa o rendimiento (B) de las plantas y los peces al inicio y al final del periodo experimental. Se observó adaptación de siete de las ocho especies de plantas autóctonas, a los módulos acuapónicos experimentales. La variedad de planta con mayor crecimiento fue el ayote, seguida del makuy y el güicoy. Se observaron diferencias en la altura $(\mathrm{p}=0.00001)$ y el rendimiento $(\mathrm{p}=0.00001)$ de las variedades de las plantas. La biomasa de tilapia por tanque fue ${ }_{-}=730 \pm 75.2 \mathrm{~g}$. En tal sentido, es posible cultivar plantas autóctonas de Guatemala en un sistema acuapónico.

Palabras claves: Plantas nativas de Guatemala, seguridad alimentaria, recirculación de agua, técnica de película de nutrientes (NFT), acuicultura.

\begin{abstract}
$\mathrm{T}$ he adaptation and production of eight varieties of Guatemala native plants to an aquaponics system was determined. Seven aquaponics modules with capacity to grow 80 plants and 25 tilapia (Oreochromis niloticus) organisms were used. Plants of Apazote (Dysphania ambrosioides), Makuy (Solanum nigresces), Amaranto (Amaranthus sp.) Bledo (A. cruentus), Chipilin (Crotalaria longirostrata), Chipilín de Monte (C vitellina), Ayote (Cucurbita argyrosperma) and Guicoy (C. pepo) were located randomly in the modules and evaluated. The evaluation period was 60 days. Survival $(\mathrm{S})$, size $(\mathrm{T})$, weight $(\mathrm{P})$ and biomass $(\mathrm{B})$ of plants and fish at the start and end of the experimental period were recorded. Seven of the eight varieties of plants adapted to the experimental modules showing survival rates between $83 \%$ and $100 \%$. Cucurbita argyrosperma showed the highest growth, followed by S. nigrescens and C. pepo. Differences in size $(\mathrm{p}<0.00001)$ and weight $(\mathrm{p}<0.00001)$ of plant varieties were observed. Tilapia biomass per tank was _ $730 \pm 75.2 \mathrm{~g}$. It is possible to cultivate Guatemalan native plants in an aquaponics system.
\end{abstract}

Keywords: Guatemalan native plants, water recirculation systems, nutrient film technique (NFT), aquaculture 